\title{
To the question of classification of combined working metals processes during the analysis of kinematics of the deformation zone
}

\author{
I. Dobrov • A. Semichev • E.Morozenko \\ National Metallurgical Academy of Ukraine, Dnipro, Ukraine
}

Received: 20 September 2019 / Accepted: 25 September 2019

\begin{abstract}
Theoretical and experimental studies of the kinematic parameters of the deformation zone during rolling and pressing in the rollers were performed. The general patterns and characteristic features of the movement of deformable layers of metal in the deformation zone for each of these methods of processing metals by pressure are established, which allows to classify these processes, as well as the combined rolling-extrusion process depending on the position of the neutral section in the deformation zone.

Purpose. Theoretical and experimental studies of the kinematic parameters of stationary deformation zones which clarify the classification of combined working metals processes.

Approach. When pressing in rollers, the studied material layer at the exit from the deformation zone represents a curve that has two convexities symmetrical with respect to the axis of symmetry of the deformation zone and concavity along the axis of symmetry of the deformation zone. During rolling the layer at the exit from the deformation zone represents a concave curve. When rolling-pressing the shape of the curve at the exit of the deformation zone has a slight crowning near the axis of symmetry of the deformation zone. Findings. Based on the theoretical and experimental research of the kinematics of the deformation zone, the characteristic features of the rolling, pressing and combined rolling-pressing processes are defined, which are based on the value of the neutral angle. This angle determines the slow and leading zones of the stock in the deformation zone during these processes.

Keywords: stock, rolling, rolling with tension, rolling with support, pressing in the die, pressing in rollers, rolling-pressing, deformation zone, neutral section, neutral angle.
\end{abstract}

\section{Introduction}

Currently, there is a tendency to implement the casting and rolling equipment for production of stock intended for subsequent processing by cold rolling, drawing and pressing [1-3]. Each of these methods has its advantages and disadvantages that determine of their use in specific production conditions. In this case, it is necessary to ensure the quality and accuracy of the product obtained, reduce energy consumption for deformation, simplify operation and maintenance, ensure the economic efficiency of the selected process of working metals by pressure [4]. In order to best meet these requirements, in practice, combined working materials processes are increasingly being used, such as: rolling-drawing, rolling-pressing, etc. [5-8]. In this case, there are increasing requirements to clarify the classification of these processes, taking into account their characteristic features during the deformation of stock [9].

\section{Purpose}

Theoretical and experimental studies of the kinematic parameters of stationary deformation zones to clarify the classification of combined working metals processes.

\section{Main Content of the Paper}

Let us consider the schemes of rolling processes (Fig. 1), pressing (Fig. 2) and rolling-pressing (Fig. 3). In the figures: $1-3$ the following notation is used: $h_{1}$ and $h_{0}$ - accordingly the height of the stock with unit width $b=1$ at the exit and at the entrance to the deformation zone; $\alpha_{k}$ - contact angle of the stock 1 and tools $2\left(2{ }_{r}\right.$ - during rolling, $2_{p}$-during pressing in rollers, $2_{d}$-during pressing in the die) respectively with radiuses $\left(R_{r}, R_{p}, R_{d}\right) ; L-$ length 
of the deformation zone; $\gamma^{1}$ - neutral angle dividing the deformation zone into two sections: the slow zone of the stock (painted in lilac color) and the leading zone of the stock (painted in yellow); $v_{1}$ and $v_{0}$ - accordingly, the velocity of the stock at the exit and at the entrance to the deformation zone; $T_{12, F}$ - friction force acting on the stock 1 from the side of a tool 2 in the slow zone in the direction of $v_{1} ; T_{12, Q}$ - friction force acting on the stock 1 from the side of tool 2 in the leading zone of the stock in the direction opposite to $v_{1}$;

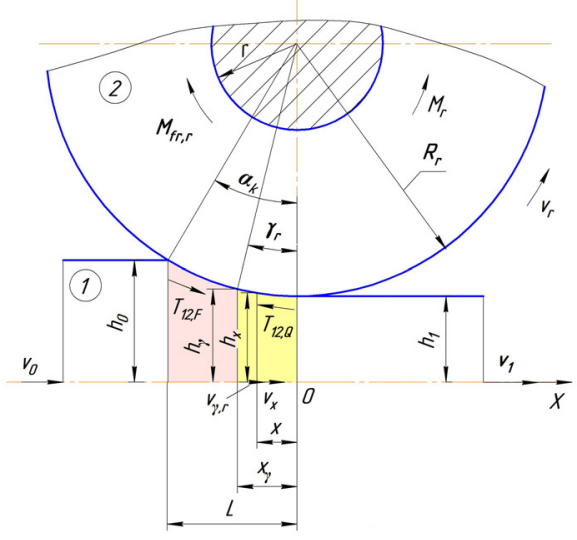

$a$

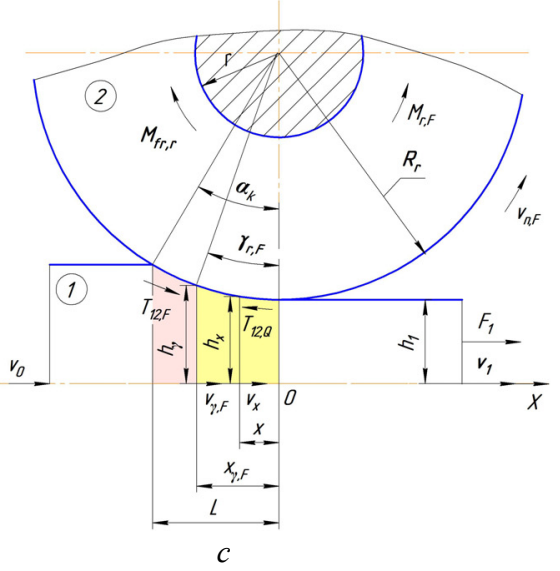

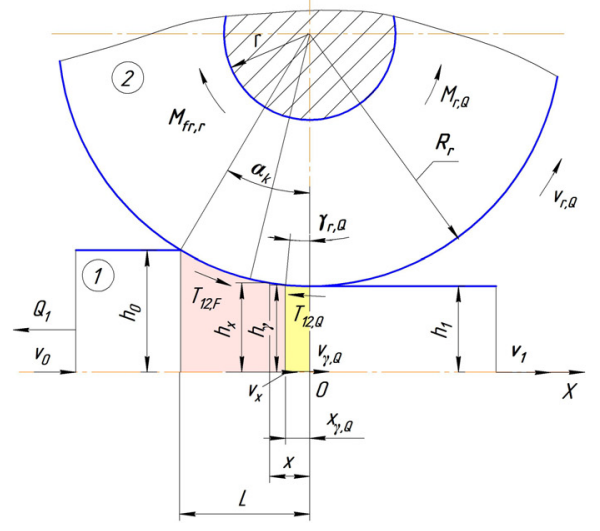

$b$

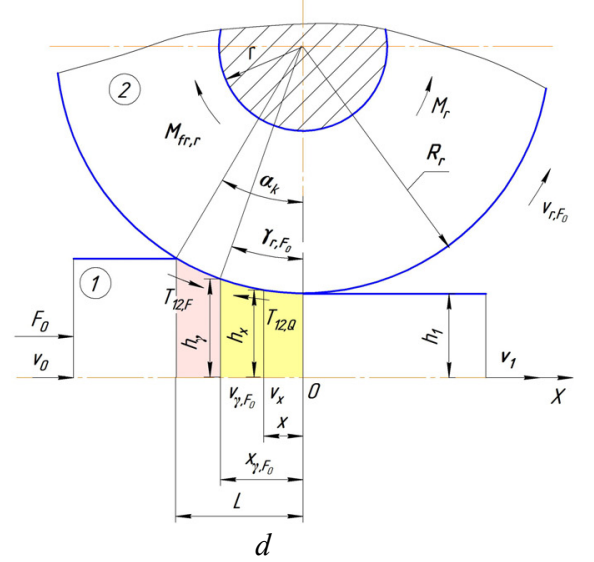

Fig. 1. Rolling methods: rolling on a smooth barrel $(a)$; front tension rolling $(b)$; rolling with back tension $(c)$; rolling with pushing $(d)$

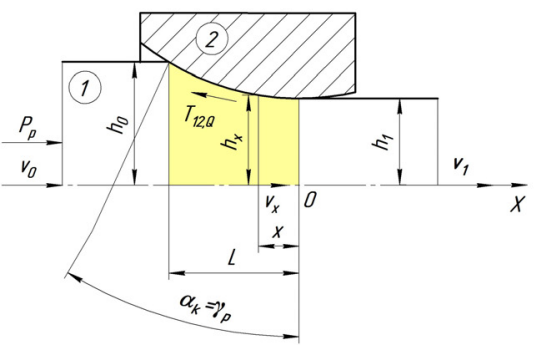

a

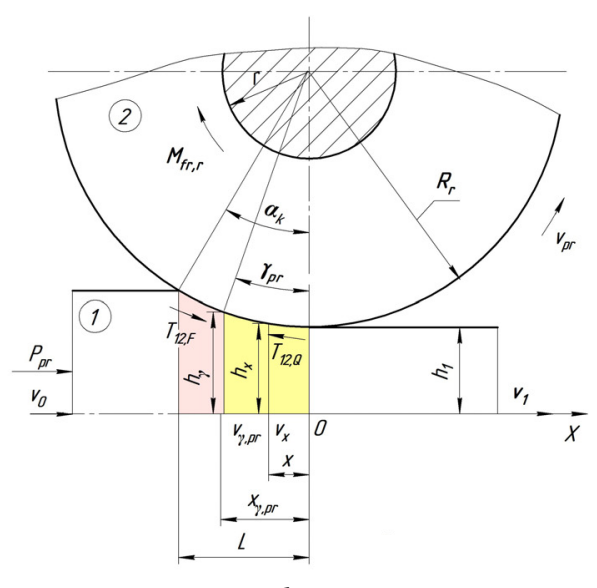

$b$

Fig. 2. Methods of pressing: in the die $(a)$; in the rollers $(b)$

\footnotetext{
${ }^{1}$ Hereinafter in the text and in figures for similar quantities for different methods working metals: rolling, pressing and during rolling-pressing, the subscript is used, consisting of the first letters of the process name $(r-$ rolling, $r, F-$ rolling with tension, $r Q-$ rolling with back tension, $r, F_{0}$ - rolling with pushing, $p r$ - pressing in rollers, $r$ - $p r$ - rolling-pressing)
} 
$h_{x}$ и $h_{\gamma}$-accordingly the height of the stock at a distance $x$ and $x_{\gamma}$ from exit from the deformation zone; $v_{x}$ and $v_{\gamma}$ - accordingly, the cross section velocity of the stock with height $h_{x}$ and $h_{\gamma} ; v$ - linear tool rotation velocity 2 ; $M_{f r, r}$ - friction moment in the support of a rotating tool 2 with radius $r ; M$ - moment of rolling.

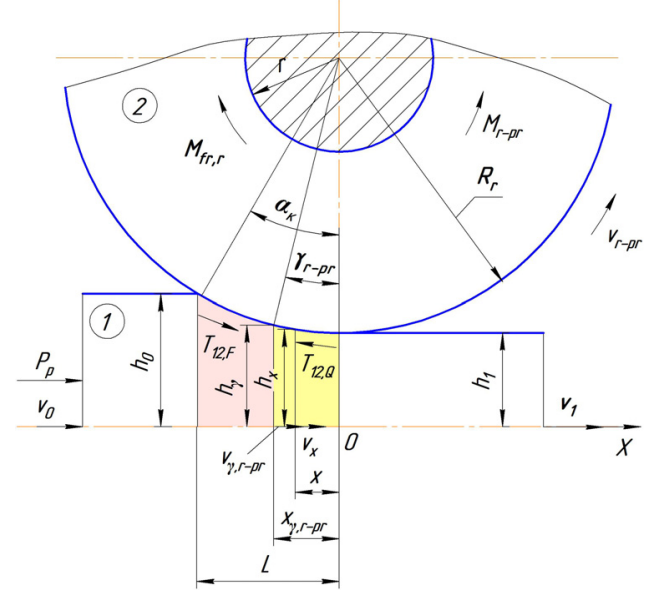

Fig. 3. Scheme of the rolling-pressing process

Regardless of the working metals method (Fig.: $1-3$ ), the velocity of the current section of a stock with a height $h_{x}$, based on the condition of material continuity in the deformation zone [9-11]

$$
v_{x}(x)=v_{1} \frac{h_{1}}{h_{x}(x)} \neq \text { const }
$$

and is not a constant value along the length of the deformation zone $(0 \leq|x| \leq|L|)$.

At the same time, the velocity of the neutral section of the stock in the deformation zone (Fig. 1, Fig. 2 b, Fig. 3) is a constant value

$$
v_{\gamma}(x)=v_{1} \frac{h_{1}}{h_{\gamma, x}(x)}=v_{1} \frac{h_{1}}{h_{1}+R(1-\cos \gamma)}=v=\text { const },
$$

and for $h_{x}=h_{\gamma}$ the velocity of the point of the neutral section of the stock on the contact surface with a rotating tool in the deformation zone is equal to the liner velocity of the rotation of the tool. If $h_{x}>h_{\gamma}$ on the contact surface of the deformation zone, the velocity of rotation of the tool 2 is greater than velocity of the points of the contact surface of the stock 1 and the resulting sliding friction force between the stock and the rotating tool $T_{12, F}$ acts in the direction of velocity $v_{1}$, and the area of the deformation zone from the entrance to the deformation zone to the neutral section is the slow zone of the stock. If $h_{x}<h_{\gamma}$ the velocity of rotation of the tool 2 is less than the velocity of the points of the contact surface of the stock 1 and the resulting sliding friction force between the stock and the rotating tool $T_{12, Q}$ acts in the direction opposite to the velocity $v_{1}$, and the area of the deformation zone from the neutral section to the exit from the deformation zone is the leading zone of the stock. Force interaction $T_{12, F}$ and $T_{12, Q}$ provides deformation of the stock under conditions of all-round compression.

For various rolling methods (Fig. 3), the neutral angle is determined by the equations [10]: for rolling on a smooth barrel (Fig. $1 a$ )

$$
\sin \gamma_{r}=\frac{\sin \alpha_{k}}{2}-\frac{1-\cos \alpha_{k}}{2 f}
$$

for rolling with back tension (Fig. $1 b$ )

$$
\sin \gamma_{r, Q}=\frac{\sin \alpha_{k}}{2}-\frac{1-\cos \alpha_{k}}{2 f}-\frac{Q_{1}}{p_{a v} f b R_{r}} ;
$$


for rolling with front tension (Fig. $1 c$ )

$$
\sin \gamma_{n, F}=\frac{\sin \alpha_{k}}{2}-\frac{1-\cos \alpha_{k}}{2 f}+\frac{F_{1}}{p_{a v} f b R_{r}} ;
$$

respectively, for rolling with pushing (Fig. $1 d$ )

$$
\sin \gamma_{r, F_{0}}=\frac{\sin \alpha_{k}}{2}-\frac{1-\cos \alpha_{k}}{2 f}+\frac{F_{0}}{p_{a v} f b R_{r}},
$$

where $f$-coefficient of external friction in the deformation zone; $p_{a v}$-average pressure on the contact surface of the deformation zone.

Analysis of equations (3) - (6) shows that $\gamma_{r}$ and $\gamma_{r, Q}$ are always less than $0,5 \alpha_{k}$, and $\gamma_{r, F}, \gamma_{r, F_{0}}$ can be smaller, equal or greater than the $0,5 \alpha_{k}$. In this case, the action of force $F_{0}$ on the stock in the entrance to the deformation zone is similar to the action of the pressing force (Fig. 2).

For pressing the stock in rollers (Fig. $2, b$ ) the neutral angle $\gamma_{p r}$ like the neutral angle when drawing in rollers is determined by the equation $[9,12]$

$$
\gamma_{p r}=0,5 \alpha_{k}\left(1+\frac{f_{p r}}{f}\right)
$$

where $f_{p r}=\frac{f_{r} r}{R_{r}}$-reduced friction coefficient taking into account the effect of $M_{f r}$ in a roller support with a radius $r$ with friction coefficient in the support $f_{r}$.

From equation (7) it follows that when pressing $\gamma_{p r}$ can take boundary value $\gamma_{p r}=0,5 \alpha_{\kappa}$ (if $M_{f r}=0$ ) and $\gamma_{p r}=\alpha_{\kappa}$, when $M_{f r}$ provides a stop of the roller and the pressing process is carried out in a die (Fig. $2 a$ ). In this case, in a die, the friction force $T_{12, Q}$ on the entire contact surface of the deformation zone provides the condition of allround compression of the stock, and we can assume that in this case for the radial profile die in axial section $\alpha_{k}=\gamma_{p r}$.

From the equations (6) and (7) it follows if $\gamma_{r, F_{0}}=\gamma_{p r}=0,5 \alpha_{\kappa}$ than force $F_{0}$ during rolling (Fig. $1 c$ ) can equally represent $P_{p r}$ when pressing in rollers (Fig. $2 b$ ) and the process of deformation of the stock under these conditions is a combined rolling-pressing process (Fig. 3), the kinematic parameters of which are characterized by a neutral angle

$$
\gamma_{r-p r}=0,5 \alpha_{\kappa}
$$

For a qualitative research of local deformations of the stock material in the deformation zone for various working metals methods, a method and device for its implementation were developed (Fig. 4 a) [11,13-16]. The device is a model of the deformation zone, which contains the base 0 . On this base there is one layer of magnetized metal balls (cylindrical parts) of various colors $\left(1\right.$ and $\left.1^{\prime}\right)$, representing the centers of masses of the elementary volumes of the stock material and metal rollers 2 mounted with the opportunity to rotate. When rollers $2_{d}\left(\omega_{r}=0\right)$ are fixed and the moving multi-colored magnetized balls (cylindrical parts) 1 (white) represent the main layer of the stock material, and $1^{\prime}$ (dark) represent the test layer of the stock material the process is carried out by a punch 3 , which is located in the guides 4 and is driven by a gear train consisting of two rotating gears 5 and two movable rails 6 , connected by the punch 3 . In this case, the pressing process in the die is modeled (Fig. 4 b, c) according to the pressing scheme shown in Fig. $2 a$. When rotating the rollers $2_{r}\left(\omega_{r} \neq 0\right)$ by the balls 1 and $1^{\prime}$ due to the movement of the punch 3 , the process of pressing in rollers is simulated (Fig. $4 d, e$ ) according to the pressing scheme in Fig. $2 b$. When balls (cylindrical parts) 1 and $1^{\prime}$ move by the rotating $\left(\omega_{r}\right)$ rolls $2_{r}$ without impact of a punch 3 on the end layer of balls at the entrance to the die, the rolling process is modeled (Fig. $4 f, g$ ) according to the rolling scheme in Fig. $1 a$. When balls (cylindrical parts) move 1 and $1^{\prime}$ due to simultaneous coordinated rotation $\left(\omega_{r}\right)$ of rolls $2_{r}$ and motion of the punch 3 the rolling-pressing process is modeled (Fig. $4 h, k$ ) according to the rolling-pressing process in Fig. 3. 
An analysis of the experimental results (Fig. $4 b-k$ ) shows that during any working metals method shown in Fig.: $1-3$ in the process of deformation of the stock with a coefficient $\mu=\frac{h_{0}}{h_{1}}$ the studied rectilinear layer of the stock material at the entrance to the deformation zone (Fig. $4 b, d, f, h$ ) changes its shape at the exit from the deformation zone (Fig. $4 c, e, g, k$ ). When pressing in a die (Fig. $4 b, c$ ), the studied layer of the stock material at the exit from the deformation zone acquires the shape that has convexity in the direction $v_{1}$. When pressing in rollers (Fig. $4 d$, e), the studied material layer at the exit from the deformation zone represents a curve that has two convexities symmetrical with respect to the axis of symmetry of the deformation zone in the direction $v_{1}$ and concavity along the axis of symmetry of the deformation zone. During rolling (Fig. $4 f, g$ ), the layer at the exit from the deformation zone in the direction $v_{1}$ represents a concave curve. When rolling-pressing the shape of the curve at the exit of the deformation zone in the direction $v_{1}$ has a slight crowning near the axis of symmetry of the deformation zone.

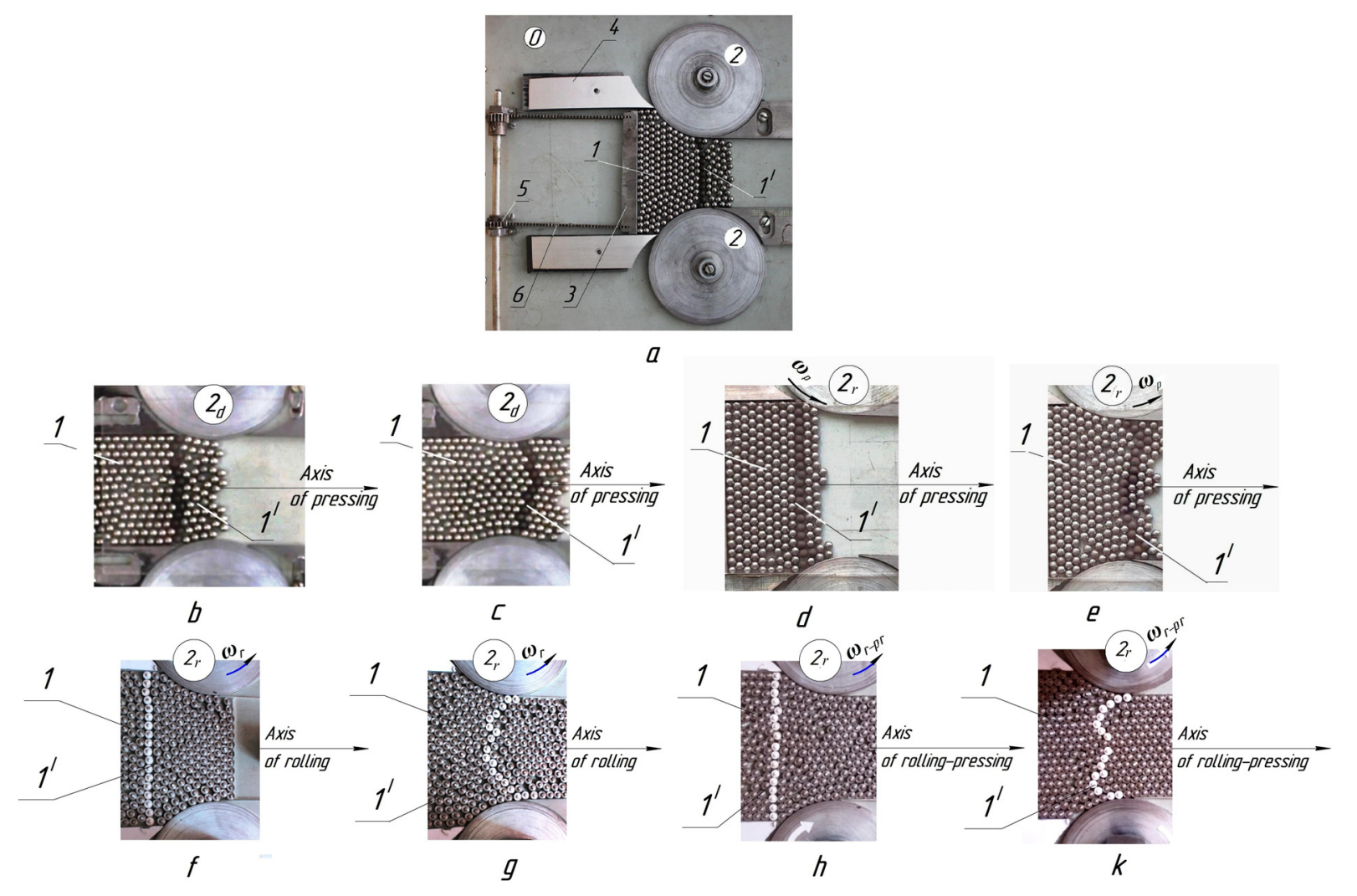

Fig. 4. Equipment for modeling local deformations of metal working processes $(a)$ and the results of process modeling: pressing $\mu=1,07$ in the die $(b, c)$ [16]; pressing $\mu=1,25$ in rollers $(d, e)[16]$; rolling $\mu=1,4(f, g)$ : rolling-pressing $\mu=1,45(h, k)$

\section{The discussion of the results}

In the axial section of the deformation zone, the vertical layer of the stock material at the entrance to the deformation zone during deformation changes its shape due to local deformations of the stock material relative to the middle vertical line of the deformable layer, the elements of which are in front of the middle line, on the middle line, and after this line if it is considered the direction along the deformation.

The position of the neutral section in the deformation zone, which simultaneously satisfies the position of the neutral section during rolling with pushing and pressing in the rollers, determines the combined rolling-pressing process, in which the neutral angle of the deformation zone is equal to half the contact angle of the stock and the rotating tool.

The impact of external friction on the contact surface of the stock in the deformation zone determines at the exit of the deformation zone the change in the initial shape of the stock material layer at the entrance to the deformation zone.

- under the conditions of pressing the stock in the die, the external friction forces that are constant in the direction, counteracting the pressing force, brake the outer layers of the stock material and provide a convexity of the deformable initial layer of the stock material, respectively, reducing the plasticity reserve of the finished product. 
- under rolling conditions, the stock is subjected to friction forces directed towards each other, but the rolling process provides the friction force acting on the stock in the slow zone of the deformation zone, which significantly exceeds the friction force opposing it in the leading zone of the deformation zone. The interaction of these forces acting on the stock in the deformation zone ensures the concavity of the stock material layer at the exit from the deformation zone, in which the plasticity reserve of the finished product is reduced in comparison with a similar product obtained by pressing in rollers;

- under the conditions of the rolling-pressing process, the interaction of external friction forces with the pressing force and with the force applied to the stock in the deformation zone is optimized due to the rolling moment. This reduces the curvature of the initial layer of the stock at the exit of the deformation zone, providing an increase in the plasticity resource of the finished product in comparison with a similar product obtained by both rolling and pressing in rollers.

\section{Conclusion}

Based on theoretical and experimental research of the kinematics of the deformation zone, it was found:

- with various rolling methods (a simple rolling process, rolling with front or back tension, rolling with pushing), the value of the neutral angle in the deformation zone is less than half the contact angle between stock and the rotating tool (roll);

- when pressing in rollers, the value of the neutral angle in the deformation zone exceeds the half the contact angle between the stock and the rotating tool;

- when pressing in a die, the neutral angle is equal to the contact angle between the stock and the tool;

- when the rolling-pressing process is combined, the neutral angle of the deformation zone is equal to half the contact angle between the stock and the rotating tool, which helps to increase the plasticity resource of the finished product at the exit of the deformation zone compared to similar products obtained during separate rolling and pressing processes.

\section{References}

1. Коновалов Ю. В. Настоящее и будущее литейно-прокатных агрегатов / Ю. В. Коновалов // Производство проката. 2009. - № 9. - С. $37-43$.

2. Логинов Ю. Н. Сравнительный анализ процессов холодной сортовой прокатки и волочения проволоки из латуней / Ю. Н. Логинов, А. Ю. Горланов, О. Л. Мурзинов // Производство проката. - 2005. - № 1. - С. 16 - 19.

3. Перерва А. В. Прессование из заготовки неограниченной длины / А. В. Перерва, Г. В.Кожевников, Л. И.Алиева // Вісник Донбаської державної машинобудівної академії 2010. - № 1 (18). - С. 221 - 225.

4. Райков Ю.Н. Экономика предприятий обработки цветных металлов. М.: Интермет-Инжиниринг, 2003. Present 336 c.

5. Минаев А. А. Совмещенные металлургические процессы / А. А. Минаев. - Донецк: Унитех, 2008. - 552 с.

6. Выдрин В. Н. Производство листов и ленты способом «прокатка-волочение» / В. Н. Выдрин, Л. М. Агеев. - М.: Черметинформация, 1971. - $21 \mathrm{c.}$

7. Титов В.А. Особенности течения металла в цилиндрическом канале матрицы при прессовании с перемешиванием / В.А. Титов, Л.В. Шмелева // Вестник НТТУ “КПИ”. Серия машиностроение. - 2013. - № 67. - С. 214 - 224. https://doi.org/10.20535/2305-9001.2013.67.37878

8. Огинский И. К. Совмещенные процессы в обработке металлов давлением / И. К Огинский, К. В. Таратута, С. Н. Востоцкий //Обработка материалов давлением. - 2018. - № 1 (46). - С.167 - 174.

9. Добров И. В. Сравнительный анализ процессов прокатки и волочения в роликовых волоках / И. В. Добров, А. П. Грудев, Ю. И. Коковихин // Изв. вуз. Черная металлургия. - 1987. - № 10. - С. 44 - 48.

10. Теория прокатки / Целиков А.И., Томленов А.Д., Зюзин В.И., Третьяков А.В., Никитин Г.С. Справочник. - Москва: Металлургия, 1982. -335 с.

11. Dobrov I. V. On Kinematics - of Stock Deformation Process during Drawing / I. V. Dobrov // Procedia Engineering. - 2017. - Vol. 206. - Pp. $760-770$.

12. Добров И. В. Энергосиловые параметры процесса волочения в роликовой волоке / И. В. Добров // Изв. вузов. Цветная металлургия. - 2009. - № 3. - С. 34 - 39.

13. Пат. 118653 Україна, МПК G01B11 / 16. Метод моделювання локальної пластичної деформації / I. В. Добров, А. В. Сьомічев, I. І. Гетьман. - №o u201610915; Заявл. 31 жовтень 2016; опубл. 28 серпень 2017, Бюл. №. 16. - 3 с.

14. Добров И. В. Исследование кинематики очага деформации осесимметричной заготовки при осадке плоскими бойками / И. В. Добров // Обработка материалов давлением. - 2013. - № 4 (37). - С.8 - 15.

15. Dobrov I. V. Optical method of physical simulation of local deformation during strip drawing using monolithic tool / I.V. Dobrov, A.V. Semichev, E.P. Morozenko, A.V. Koptilyy // Working of materials by pressure. - Kramatorsk: DGMA, 2018. - No. 2 (47). - pp. $26-30$.

16. Dobrov I.V. To the question of the mechanics of the deformation zone during pressing of the strip / I.V. Dobrov, A.V. Semichev, O.P. Morozenko, O.V. Koptilyy // International Scientific and Technical Conference "Progressive Technology Technology and Engineering Education", Kyiv, 3 - 7 June 2019: Materials of the Conference - Kyiv: 2019. - pp. 93 - 95. 


\title{
К вопросу классификации совмещенные процессы ОМД при анализе кинематики очага деформации
}

\author{
И. В. Добров, А. В. Семичев, Е. П. Морозенко
}

\begin{abstract}
Аннотация. Выполнены теоретические и экспериментальные исследования кинематических параметров очага деформации при прокатке и прессовании в роликах и фильере. Установлены общие закономерности и характерные особенности перемещения деформированных слоев материала в очаге деформации для каждого способа обработки материалов давлением, что позволяет классифицировать эти прочессы, а также прочесс прокатки-прессования в зависииости от положения нейтрального сечения в очаге деформации.
\end{abstract}

Ключевые слова: заготовка, прокатка, прокатка с натяжением, прокатка с подпором, прессование в фильере, прессование в роликах, прокатка-прессование, очаг деформации, нейтральное сечение, нейтральный угол.

\section{До питання класифікації суміщених процесів ОМТ при аналізі кінематики осередку деформації}

\section{І. В. Добров, А. В. Сьомічев, О. П. Морозенко}

Анотація. Виконано теоретичні та експериментальні дослідження кінематичних параметрів осередку деформації при прокатиі і пресуванні в роликах і філь'єрі. Встановлено загальні закономірності і характерні особливості переміщення деформованих шарів матеріалу в осередку деформаиії для кожного способу обробки матеріалів тиском, шо дозволяє класифікувати иі процеси, а також процес прокатки-пресування в залежності від положення нейтрального перетину в осередку деформачії.

Ключові слова: заготовка, прокатка, прокатка з натягом, прокатка з підпором, пресування в філь'єрі, пресування в роликах, прокатка-пресування, осередок деформації, нейтральне перетин, нейтральний кут.

\section{References}

1. Konovalov, Yu.V. (2009), "Present and future of casting and rolling aggregates", Production of rolled products, no. 9, pp. 37 - 43.

2. Loginov Yu.N. (2005), Sravnitel'nyj analiz processov holodnoj sortovoj prokatki i volochenija provoloki iz latunej [Comparative analysis of the processes of cold section rolling and wire drawing from brass] / Yu.N. Loginov, A. Yu. Gorlanov, O.L. Murzinov // Rolled metal production, no.1, pp. $16-19$.

3. Pererva, A.V., Kozhevnikov, G.V. and Alieva, L.I. (2010), "Pressing from blanks of unlimited length" The Herald of the Donbas State Power Machines Academy, vol. 18, no. 1, pp. 221 - 225.

4. Raikov, Yu.N. (2003), Jekonomika predprijatij obrabotki cvetnyh metallov [Economics of enterprises processing non-ferrous metals], Intermet-Engineering, Moscow, Russia.

5. Minaev, A.A. (2008), Sovmeshhennye metallurgicheskie processy [Combined metallurgical processes], Unitech, Donetsk, Ukraine.

6. Vydrin, V.N. and Ageev, L.M. (1971), "Proizvodstvo listov i lenty sposobom "prokatka-volochenie"” [Production of sheets and tape by the method of "rolling-drawing"], Chermetinformation, Moscow, Russia.

7. Titov, V.A. and Shmeleva, L.V. (2013), "Features of metal flow in a cylindrical channel of a matrix during pressing with mixing", Journal of Mechanical Engineering NTUU “Kyiv Polytechnic Institute", no. 67, pp 214 - 224, https://doi.org/10.20535/23059001.2013.67.37878

8. Oginsky, I.K. K. V. Taratuta, S. N. Vostotsky (2018), “Combined processes in the processing of metals by pressure”, Processing of materials by pressure., vol. 46, no. 1, pp.167- 174.

9. Dobrov, I.V., Grudev, A.P. and Kokovikhin, Yu.I. (1987), “Comparative analysis of rolling and dragging processes in roller walkways", Izv. high school. Ferrous metallurgy, no. 10, pp. $44-48$.

10. Tselikov, A.I., Tomlenov, A.D., Zyuzin, V.I., Tretyakov, A.V. and Nikitin, G.S. (1982), Teorija prokatki [Theory of rolling], Directory, Metallurgy, Moscow, Russia.

11. Dobrov, I.V. (2017), "On Kinematics - of Stock Deformation Process during Drawing”, Procedia Engineering, vol. 206 , pp. 760 - 770.

12. Dobrov, I.V. (2009), Energy parameters of the process of drawing in a roller die, Izv. universities. Non-ferrous metallurgy, no. 3 . pp. 34 - 39.

13. Dobrov, I.V., Semichev, A.V. and Getman, I.I. (2016), Metod modeljuvannja lokal'noï plastichnoï deformaciï [A method for modeling the kinematics of local plastic deformation], Ukraine. No u201610915; posted 31 of October 2016; publ. 28 of August 2017, Bul. no. 16, MPK G01B11/16, Ukraine, Pat. 118653.

14. Dobrov, I.V. (2013), "Investigation of the kinematics of the deformation zone of an axisymmetric billet during slump by flat strikers", Processing of materials by pressure, vol. 37, no. 4, pp. $8-15$.

15. Dobrov, I.V., Semichev, A.V., Morozenko, E.P. and Koptilyy, A.V. (2018), "Optical method of physical simulation of local deformation during strip drawing using monolithic tool", Working of materials by pressure, Kramatorsk, $D G M A$, vol. 47, no. 2, pp. 26 - 30.

16. Dobrov, I.V. Semichev, A.V., Morozenko, O.P. and Koptilyy, O.V. (2019), "To the question of the mechanics of the deformation zone during pressing of the strip", International Scientific and Technical Conference "Progressive Technology Technology and Engineering Education", Kyiv, 3 - 7 June 2019, Materials of the Conference, Kyiv, pp. 93 - 95. 